\title{
Soil pH and exchangeable aluminium in contrasting New Zealand high and hill country soils
}

\author{
A.E.WHITLEY ${ }^{1}$, J.L. MOIR ${ }^{1}$, P.C. ALMOND ${ }^{1}$ and D.J. MOOT ${ }^{2}$ \\ ${ }^{1}$ Department of Soil and Physical Sciences \\ ${ }^{2}$ Department of Agricultural Sciences \\ Lincoln University, PO Box 85084, Lincoln Canterbury, New Zealand \\ amy.whitley@lincolnuni.ac.nz
}

\begin{abstract}
Soil acidity and associated aluminium (Al) toxicity severely limit the establishment and growth of legumes in New Zealand high country pastures. A survey of 13 soils differing in location, soil order, parent material and climate, showed soil $\mathrm{pH}$ to range from 4.9 to 6.4 and exchangeable $\mathrm{Al}\left(0.02 \mathrm{M} \mathrm{CaCl}_{2}\right)$ concentrations of $<0.5$ to $23.3 \mathrm{mg} / \mathrm{kg}$. At all sites and at varying soil $\mathrm{pH}$ and profile depths, $\mathrm{Al}$ was present at concentrations above the toxicity threshold for sensitive legumes. Brown soils had the overall highest $\mathrm{Al}$ concentrations from 0.8 to $23.3 \mathrm{mg} / \mathrm{kg}$, and volcanic soils the lowest from $<0.5$ to $6.7 \mathrm{mg} / \mathrm{kg}$. The soil and environmental factors other than soil $\mathrm{pH}$ that drive variability in soil exchangeable $\mathrm{Al}$ require further investigation.
\end{abstract}

Keywords: soil $\mathrm{pH}$, soil exchangeable aluminium, toxicity, soil type

\section{Key messages}

- The concentration of soil exchangeable $\mathrm{Al}$, which can be toxic to legumes, was measured at 13 sites, at different profile depths and soil $\mathrm{pH}$ values

- Al toxicity extended across many soil orders and climatic zones in New Zealand

- Brown soils showed the highest Al concentrations from 0.8 to $23.3 \mathrm{mg} / \mathrm{kg}$, while the volcanic soils overall had much lower Al from $<0.5$ to $6.7 \mathrm{mg} / \mathrm{kg}$.

\section{Introduction}

The New Zealand high and hill country environment is often characterised by temperature extremes, a short growing season and seasonal moisture deficits (Scott et al. 1985). These climatic limitations coupled with acidic and often low fertility soils (N, P and S) can limit the establishment and growth of legumes (Haynes \& Williams 1993).

Furthermore, soil aluminium (Al) toxicity occurs on many NZ high and hill country farms. Al availability is affected by soil $\mathrm{pH}$ but the relationship is poorly understood across soil orders. Higher concentrations of exchangeable soil $\mathrm{Al}\left(\mathrm{Al}^{3+}\right)$ can damage plant roots, and reduce pasture growth (Scott et al. 2008). In particular, Al toxicity affects legumes, which supply $\mathrm{N}$ and provide high quality feed for stock.

The threshold concentration of exchangeable $\mathrm{Al}$ for sensitive pasture legumes has been stated as $3 \mathrm{mg} /$ $\mathrm{kg}(0.02 \mathrm{M} \mathrm{CaCl})$, above which toxicity may occur (Moir et al. 2016). $\mathrm{Al}^{3+}$ has been suggested as the most plant-toxic $\mathrm{Al}$ form, with other forms being less toxic (Manoharan et al. 1996). However, the sensitivity of legumes to $\mathrm{Al}$ is variable and species specific. To mitigate $\mathrm{Al}$ toxicity, we need to understand which soils are most susceptible and what factors, other than soil $\mathrm{pH}$, are involved. Therefore, the objective of this study was to measure the soil $\mathrm{pH}$ and exchangeable $\mathrm{Al}$ down the soil profile at different sites in New Zealand. This paper represents preliminary data contributing to a larger scale dataset.

\section{Methods}

Field soil sampling was conducted at sites with known acidity and $\mathrm{Al}$ issues to determine the $\mathrm{pH}$ and exchangeable $\mathrm{Al}$ concentrations of different soils across New Zealand. The locations included Canterbury, Central Otago, Marlborough, Gisborne, Waikato and Taupo. Sites varied in seasonal/annual climate (NIWA Core funded project Climate Present and Past CAOA1501), soil type, parent material and elevation (Table 1) and had a history of minimal lime inputs since land development. Soil pits were dug at all sites, profiles described and samples taken at $10 \mathrm{~cm}$ depth increments to $1 \mathrm{~m}$ or to gravel. The samples were analysed for $\mathrm{pH}\left(\mathrm{H}_{2} \mathrm{O}\right)$ (1:2.5 soil: water ratio) (Blakemore et al. 1987) and exchangeable $\mathrm{Al}$, using the $0.02 \mathrm{M} \mathrm{CaCl}_{2}$ extraction method, and quantified using inductively coupled plasma atomic emission spectroscopy (ICPOES: Varian 720-ES ICP-OES; Varian Inc., Victoria, Australia) analysis.

Soil order was derived from the New Zealand Soil Classification (Hewitt 1992).

\section{Results}

\section{Soil $\mathrm{Al}$ and $\mathbf{p H}$}

Soil exchangeable $\mathrm{Al}$ ranged from $<0.5 \mathrm{mg} / \mathrm{kg}$ to 22.1 $\mathrm{mg} / \mathrm{kg}$ and $\mathrm{pH}$ varied from 4.9 to 6.4 (Table 2). The highest exchangeable $\mathrm{Al}$ was measured in a Brown soil from Hawea (GF). This soil is highly acidic $(\mathrm{pH}$ 
4.9 to 5.2) throughout the profile, with a mean $\mathrm{Al}$ concentration that peaked at $22.1 \mathrm{mg} / \mathrm{kg}$ in the top 10 $\mathrm{cm}$ (pH of 4.9). Exchangeable Al was consistently high throughout the profile. The Brown soil at Tekapo (GM) also had high concentrations of $\mathrm{Al}$, which also peaked in the top $10 \mathrm{~cm}$ of the soil at $12.4 \mathrm{mg} / \mathrm{kg}$ (pH of 5.0). A recent soil at Omarama (OM) contained $\mathrm{Al}$ at $13.0 \mathrm{mg}$ / $\mathrm{kg}$ in the top $10 \mathrm{~cm}$ (pH of 5.3).

Many sites had lower concentrations of $\mathrm{Al}$ at the soil surface, but exhibited acidity and associated higher Al concentrations with increasing depth. These included soils from Gisborne (PK), Waikato (WT) and Canterbury (CA). The lowest $\mathrm{Al}$ value measured was $<0.5 \mathrm{mg} / \mathrm{kg}$ for a Taupo pumice (AR) at $40-50$ $\mathrm{cm}$ in the soil profile and a soil $\mathrm{pH}$ of 6.4. However, concentrations above $3 \mathrm{mg} / \mathrm{kg}$ were observed shallower in that profile.

\section{Relationship between soil $\mathrm{pH}$ and exchangeable aluminium}

Exchangeable $\mathrm{Al}$ and soil $\mathrm{pH}$ varied among soils and geographical location. The soil $\mathrm{pH} / \mathrm{Al}$ relationship for the 116 samples (from the 13 sites at different depths) showed a moderate $\left(\mathrm{R}^{2}=0.65\right)$ exponential decay across the $\mathrm{pH}$ range of 4.9 to 6.4 (Figure 1).

Soil exchangeable Al varied significantly at any

Table 1 Site information for the 13 sites sampled across New Zealand.

\begin{tabular}{lccccc}
\hline Site & Location & $\begin{array}{c}\text { Mean Annual } \\
\text { rainfall }(\mathbf{m m})\end{array}$ & Soil order & Parent material & $\begin{array}{c}\text { Elevation } \\
(\mathbf{m} \text { a.s.I) }\end{array}$ \\
\hline AR & Taupo & $1000-1300$ & Pumice & Pumice (rhyolitic) & 495 \\
PK & Gisborne & $1600-2000$ & Pumice & Pumice (rhyolitic) & 495 \\
WT & Waikato & $1000-2000$ & Allophanic & Ash (andesitic) & 84 \\
MO & Marlborough & $1000-1300$ & Brown & Sedimentary (colluvium) & 914 \\
GM & Tekapo & $800-850$ & Brown & Sedimentary (moraine) & 765 \\
OM & Omarama & $500-600$ & Recent & Sedimentary (alluvial) & 489 \\
BD & Omarama & $1000-1200$ & Brown & Sedimentary (alluvial) & 545 \\
LP & Tarras & $700-800$ & Pallic & Sedimentary (loess) & Sedimentary \\
GF & Hawea & $600-800$ & Brown & Sedimentary & 786 \\
MG & Hawea & $600-800$ & Brown & Brown & Sedimentary (outwash surface) \\
CA & Canterbury & $800-1000$ & Brown & Sedimentary (moraine) & 701 \\
EM & Canterbury & $1000-1200$ & Brown & Sedimentary (moraine) & 717 \\
HE & Canterbury & $1200-1400$ & & & 735 \\
\hline
\end{tabular}

Table 2 Exchangeable Al and soil pH at different depths in the soil profiles of $13 \mathrm{NZ}$ high and hill country soils.

\begin{tabular}{|c|c|c|c|c|c|c|c|c|c|c|}
\hline \multirow[t]{2}{*}{ Site } & \multicolumn{2}{|l|}{$0-10 \mathrm{~cm}$} & \multicolumn{2}{|c|}{$10-20 \mathrm{~cm}$} & \multicolumn{2}{|l|}{$20-30 \mathrm{~cm}$} & \multicolumn{2}{|l|}{$30-40 \mathrm{~cm}$} & \multicolumn{2}{|c|}{$40-50 \mathrm{~cm}$} \\
\hline & $\begin{array}{c}\mathrm{pH} \\
\left(\mathrm{H}_{2} \mathrm{O}\right)\end{array}$ & $\begin{array}{l}\text { Exch Al } \\
(\mathrm{mg} / \mathrm{kg})\end{array}$ & $\begin{array}{c}\mathrm{pH} \\
\left(\mathrm{H}_{2} \mathrm{O}\right)\end{array}$ & $\begin{array}{l}\text { Exch Al } \\
(\mathrm{mg} / \mathrm{kg})\end{array}$ & $\begin{array}{c}\mathrm{pH} \\
\left(\mathrm{H}_{2} \mathrm{O}\right)\end{array}$ & $\begin{array}{l}\text { Exch Al } \\
(\mathrm{mg} / \mathrm{kg})\end{array}$ & $\begin{array}{c}\mathrm{pH} \\
\left(\mathrm{H}_{2} \mathrm{O}\right)\end{array}$ & $\begin{array}{l}\text { Exch Al } \\
(\mathrm{mg} / \mathrm{kg})\end{array}$ & $\begin{array}{c}\mathrm{pH} \\
\left(\mathrm{H}_{2} \mathrm{O}\right)\end{array}$ & $\begin{array}{l}\text { Exch Al } \\
(\mathrm{mg} / \mathrm{kg})\end{array}$ \\
\hline AR & 5.8 & 2.5 & 5.8 & 3.3 & 6.2 & 1.1 & 6.2 & 0.5 & 6.4 & $<0.5$ \\
\hline PK & 5.6 & 1.7 & 5.7 & 4.5 & 5.8 & 5.8 & 5.9 & 4.5 & 5.9 & 2.7 \\
\hline WT & 5.7 & 2.4 & 5.7 & 4.8 & 5.9 & 1.3 & 5.9 & 0.7 & 5.9 & $<0.5$ \\
\hline $\mathrm{MO}$ & 5.4 & 6.6 & 5.5 & 6.1 & 5.6 & 4.1 & 5.7 & 3.2 & 5.7 & 2.6 \\
\hline GM & 5.0 & 12.4 & 5.4 & 6.3 & 5.1 & 11.7 & - & - & - & - \\
\hline OM & 5.3 & 13.0 & 5.1 & 11.8 & - & - & - & - & - & - \\
\hline $\mathrm{BD}$ & 5.8 & 1.8 & 5.5 & 6.1 & 5.7 & 7.1 & 5.5 & 9.8 & - & - \\
\hline LP & 5.6 & 1.5 & 5.6 & 2.1 & 5.5 & 3.1 & 5.5 & 6.5 & 5.4 & 7.9 \\
\hline GF & 4.9 & 22.1 & 4.9 & 21.3 & 5.2 & 13.7 & - & - & - & - \\
\hline$M G$ & 5.2 & 5.1 & 5.4 & 3.0 & 5.4 & 1.5 & 5.6 & 2.5 & 5.4 & 3.3 \\
\hline CA & 5.4 & 5.1 & 5.1 & 18.3 & 5.2 & 17.5 & 5.3 & 16.0 & 5.4 & 15.5 \\
\hline EM & 5.5 & 6.8 & 5.5 & 6.5 & 5.6 & 2.8 & 5.8 & 1.5 & 5.8 & 1.8 \\
\hline $\mathrm{HE}$ & 5.3 & 6.8 & 5.3 & 9.5 & 5.5 & 6.9 & 5.5 & 5.9 & 5.4 & 6.2 \\
\hline
\end{tabular}




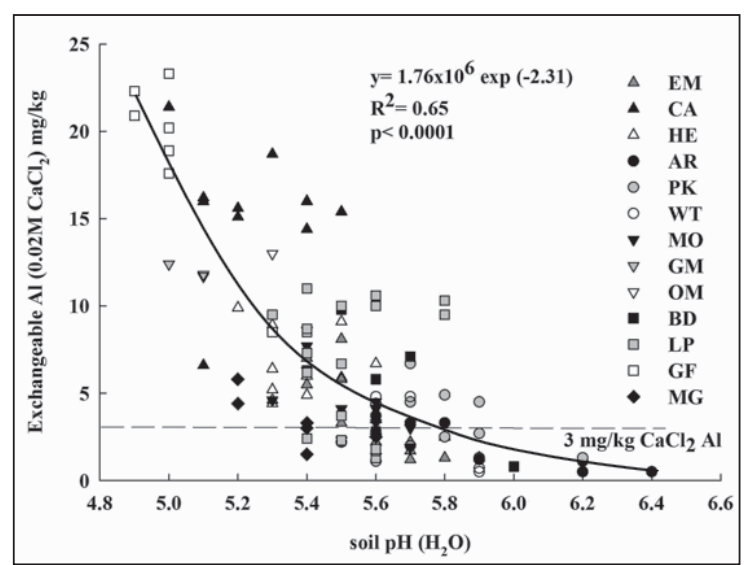

Figure 1 The relationship between soil $\mathrm{pH}\left(\mathrm{H}_{2} \mathrm{O}\right)$ and exchangeable $\mathrm{Al}\left(0.02 \mathrm{M} \mathrm{CaCl}_{2}\right.$ extractable) for 116 soil samples from 13 sites across New Zealand. (Refer to Table 1 for soil codes).

single $\mathrm{pH}$ value. Individual samples had exchangeable Al concentrations above the threshold value of $3 \mathrm{mg} /$ $\mathrm{kg}$ at $\mathrm{pH}$ values as high as 5.9 and could be below the threshold for $\mathrm{pH}$ values as low as 5.4.

Of the 13 sites sampled, Figure 1 shows that a Hawea (GF) and Canterbury (CA) site (Brown soils) had the highest concentrations of $\mathrm{Al}(>15 \mathrm{mg} / \mathrm{kg})$ in acidic $\mathrm{pH}$ conditions. The sites with the lowest $\mathrm{Al}$ were typically North Island sites with higher $\mathrm{pH}$ zones in the soil profile and included pumice and allophanic soils.

\section{Discussion}

Aluminium toxicity was widespread across the sample area. Soil concentrations of $\mathrm{Al}$ above the toxicity threshold (3 $\mathrm{mg} / \mathrm{kg}$ ) for sensitive legumes (Wheeler et al. 1992; Moir et al. 2016) were measured at all sites. The depth and soil $\mathrm{pH}$ at which $\mathrm{Al}$ peaked varied between soils. For several soils, high Al was measured in the top $20 \mathrm{~cm}$ of the soil profile (pasture root zone) while at other sites it was measured at depths $>20 \mathrm{~cm}$. The depth at which $\mathrm{Al}$ is toxic is important in terms of selection of a suitable legume and for determining the most effective remediation. Large variability was shown in the exchangeable Al concentrations measured at a single $\mathrm{pH}$, which supports the results of Moir \& Moot (2014) and extends the data to include new information about other soil orders. The soil and environmental factors which drive this variability require further analysis.

In general terms, exchangeable $\mathrm{Al}$ concentration declined with increasing soil $\mathrm{pH}$ (Figure 1). The literature suggests for soils with a $\mathrm{pH}$ below 5.5, Al toxicity poses an issue (Bishop \& Quin 2013). However, data presented here shows that soils with a $\mathrm{pH}\left(\mathrm{H}_{2} \mathrm{O}\right)$ of up to 5.9 may have $\mathrm{Al}$ concentrations that would be toxic to legumes (Figure 1). For example, the
Gisborne pumice (PK) soil at a $\mathrm{pH}$ of 5.9 has an $\mathrm{Al}$ concentration of $4.5 \mathrm{mg} / \mathrm{kg}$ at $30-40 \mathrm{~cm}$ depth. Singleton et al. (1987) found similar results on a Ruawaro clay loam (pumiceous alluvium) and a Kauwhata clay loam (volcanic ash). They found an increase in Al concentration correlated with soil acidity, but also that at $\mathrm{pH}$ values of 6 to 7 , particularly in the $0-20 \mathrm{~cm}$ depth, the $0.02 \mathrm{M} \mathrm{CaCl}_{2} \mathrm{Al}$ concentration was higher than the $3 \mathrm{mg} / \mathrm{kg}$ threshold level. These authors found that no site factors could explain the high $\mathrm{Al}$ in the topsoil. Figure 1 shows that the soil $\mathrm{pH}\left(\mathrm{H}_{2} \mathrm{O}\right)$ explained $65 \%$ of the variability in exchangeable Al. The remaining variability could be due to other soil or environmental factors, such as organic matter, clay mineralogy and properties that affect the buffering capacity of the soil and the mobility of $\mathrm{Al}$ (McCauley et al. 2003).

There was no relationship between soil Al concentrations and mean annual rainfall (MAR). The MAR range across the sites was $500-2000 \mathrm{~mm}$, from Omarama (OM) to Gisborne to the Waikato (PK, WT) and all soils had $\mathrm{Al}$ concentrations above the toxicity threshold. The two Hawea brown soils (GF and MG) had the same parent material and experience the same mean MAR and yet the GF site was much more acidic and showed much higher (more toxic) concentrations of Al compared with the MG site. This result could be related to the fertiliser history of the site, particularly application of lime. A lack of an effect of rainfall on exchangeable $\mathrm{Al}$ contrasts with the results of Webb et al (1986), who found that the leaching of bases, acidity and exchangeable $\mathrm{Al}$ increased markedly with rainfall and the degree of development of moraine soils near Lake Pukaki. However, their study isolated the variability in $\mathrm{Al}$ along a rainfall gradient (same parent material) compared with this study, which covered a larger area and a range of soil parent materials. Harrison et al. (1990) studied two chronosequences under different rainfall on moraine and terrace soils near Craigieburn, Canterbury. They showed higher exchangeable Al in moraine soils, on mountain slopes with high rainfall, compared to the terrace soils.

This field soil survey clearly shows soil order is an important factor contributing to the variability in exchangeable Al. Soil order relates to the degree of development of a soil, parent material and climatic conditions (Hewitt 1992). Data presented in this paper show that, overall, the brown soils (GF, MO, MG, GM, $\mathrm{CA}, \mathrm{EM}$ and HE sites) had higher concentrations of Al than the pallic, recent and volcanic soils. Brown soils form under higher rainfall, are older and have undergone weathering and acidification. Pallic soils occur under lower rainfall and recent soils are much younger than brown soils, which results in reduced weathering and acidification which in turn contributes to lower $\mathrm{Al}$ concentrations. Lower concentrations 
of $\mathrm{Al}$ were found in the volcanic soils (pumice and allophanic) compared with many of the South Island soils formed from greywacke. However, there was still $\mathrm{Al}$ present at concentrations above $3 \mathrm{mg} / \mathrm{kg}$ in the volcanic soils. The overall lower $\mathrm{Al}$ present in the volcanic soils is an interesting result and currently unexplained. These data indicated that high $\mathrm{Al}$ concentrations followed the sequence of Brown $>$ Pallic $>$ Recent $>$ Allophanic $\geq$ Pumice. However, this study had limited sample numbers and therefore more extensive data analyses are currently underway to confirm this result. These findings support other work conducted by Hochman et al (1992) showing high Al concentrations in New Zealand brown soils.

This field survey involved the collection of soil profile samples at 13 sites in New Zealand to determine the $\mathrm{pH}$ and exchangeable $\mathrm{Al}$ concentrations. The next phase will use legumes as bio-indicators to determine if the soil $\mathrm{Al}$ toxicity measure $\left(\mathrm{CaCl}_{2}\right.$ extraction) equates to plant growth.

\section{ACKNOWLEDGEMENTS}

Ballance Agri-Nutrients Ltd provided funding for this research. Sephrah Rayner, Lyn Carmichael, and Natasha Barbier assisted in fieldwork in association with Landcare Research. Landcorp farms Ltd, Peter Jordan, the farmers and Duncan Clarke.

\section{REFERENCES}

Blakemore, L.C.; Searle, P.L.; Daly, B.K.1987. Methods of chemical analysis of soils. New Zealand Soil Science Bureau, Volume 80, Lower Hutt.

Bishop, P.; Quin, B.F. 2013. Undiagnosed metal phytotoxicity in soils: Measurement of soil $\mathrm{pH}$ micro-variability under Manawatu pastures and an assessment of an alternative means of amelioration. Proceedings of the New Zealand Grassland Association 75: 179-184.

Harrison, R.; Swift, R.S.; Campbell, A.S.; Tonkin, P.J. 1990. A study of two soil development sequences located in a montane area in Canterbury, New Zealand, I. Clay mineralogy and cation exchange properties. Geoderma 47: 261-282.

Haynes, R.J.; Williams, P.H. 1993. Nutrient cycling and soil fertility in the grazed pasture ecosystem. Advances in Agronomy 49: 120-199.

Hewitt, A.E. 1992. New Zealand Soil Classification. DSIR Land Resources Scientific Report No.19.

Hochman, Z.; Edmeades, D.C.; White, E. 1992. Changes in effective cation exchange capacity and exchangeable aluminium with soil $\mathrm{pH}$ in lime- amended field soils. Australian Journal of Soil Research 30: 177-187.

Manoharan, V.; Loganathan, P.; Parfitt, R. L.; Tillman, R. W. 1996. Changes in soil solution composition and aluminium speciation under legume-based pastures in response to long-term phosphate fertiliser applications. Australian Journal of Soil Research 34: 985-998.

McCauley, A.; Jones, C.; Jacobsen, J. 2003. Soil pH and organic matter. In: M.S. University. Nutrient Management - a self-study course from the MSU extension service continuing education series. Accessed: 14/10/15. http://landresources.montana. edu/nm/documents/NM8.pdf

Moir, J.L.; Jordan, P.; Moot, D.J. 2016. Phosphorus response and optimum $\mathrm{pH}$ ranges of twelve pasture legumes grown in an acid upland New Zealand soil under glasshouse conditions. Soil Science and Plant Nutrition (In Press).

Moir, J.L.; Moot, D.J. 2014. Medium term soil $\mathrm{pH}$ and aluminium response to liming in three high country locations. Proceedings of the New Zealand Grassland Association 76: 41-46.

Moir, J.L.; Moot, D.J. 2010. Soil pH, exchangeable aluminium and lucerne yield responses to lime in a South Island high country soil. Proceedings of the New Zealand Grassland Association 72: 191-195.

Scott, B.J.; Ewing, M.A.; Williams, R.; Humpheries, A.W.; Coombes, N.E. 2008. Tolerance of aluminium toxicity in Annual Medicago species and lucerne. Australian Journal of Experimental Agriculture 48: 499-511.

Scott, D.; Keoghan, J.M.; Cossens, G.G.; Maunsell, L.A.; Floate, M.J.S.; Wills, B.J.; Douglas, G. 1985. Limitations to pasture production and choice of species. Using Herbage Cultivars. Grassland Research and Practice Series 3: 9-15.

Singleton, P.L.; Edmeades, D.C.; Smart, R.E.; Wheeler, D.M. 1987. Soil acidity and aluminium and manganese toxicity in the Te Kauwhata area, North Island, New Zealand. New Zealand Journal of Agricultural Research 30: 517-522.

Webb, T.H.; Campbell, A.S.; Fox, F.B. 1986. Effect of rainfall on pedogenesis in a climatosequence of soils near Lake Pukaki, New Zealand. New Zealand Journal of Geology and Geophysics 29: 323-334.

Wheeler, D.M.; Edmeades, D.C.; Christie, R.A.; Gardner, R. 1992. Effect of aluminium on the growth of 34 plant species: A summary of results obtained in low ionic strength solution culture. Plant and Soil 146: 61-66. 